\title{
ANALISIS KEPUASAN PENGUNJUNG PADA DINAS PERPUSTAKAAN DAN ARSIP DAERAH PROVINSI PAPUA
}

\author{
Penulis: \\ Karen Meike Mamahit ${ }^{1}$ \\ mamahit.meike11919@gmail.com
}

\begin{abstract}
Abstrak
This paper presents the results of a study of the effect of library service satisfaction provided by the Provincial Government of Papua. Destruction services are provided through the Regional Library and Archives Service work unit. The independent variable is the service of human resources, the availability of facilities and infrastructure, and information systems. This study uses survey results and documents. The findings explain, that the three independent variables have a positive and significant effect, but the human resource variable has the most dominant influence compared to the other two variables.
\end{abstract}

Keywords: kepuasan pengunjung

\section{PENDAHULUAN}

Perpustakaan merupakan satu organisasi berlokasi di tempat tertentu, mengumpulkan, menyimpan dan mengelolah bahan pustaka untuk dipergunakan secara berkesinambungan sebagai sumber informasi oleh para pemakainya. Perpustakaan menyediakan koleksi bahan pustaka untuk dilayankan kepada masyarakat secara umum. Perpustakaan harus dapat memberikan informasi kepada pengguna, memberikan kesempatan kepada pengguna untuk tujuan pembelajaran dan penelitian. Intinya sebuah perpustakaan mempunyai fungsi informasi. Selain itu perpustakaan juga menjalankan fungsi rekreasi, tersedia banyak bacaan dan vidio yang sifatnya menghibur.

Tujuan perpustakaan memberi layanan kepada warga masyarakat yang membutuhkan bahan bacaan atau pustaka. Untuk maksud itu bahan pustaka wajib dikelolah baik sesuai kebutuhan pembaca. Bahan bacaan pustaka yang di kumpulkan terutama ditujukan agar dapat digunakan pengguna atau pembaca. Sedangkan maksud

\footnotetext{
1 Dinas Perpustakaan dan Arsip Daerah Provinsi Papua
} 
pengolahan adalah mempermudah pencarian bahan pustaka yang dibutuhkan. Fungsi layanan pustaka lebih pada mempertemukan pembaca dengan bahan bacaan yang dibutuhkan atau diminati. Untuk itu harus diusahkan supaya perpustakaan mengadakan kegiatan yang menyenangkan pembaca yang mendatangi perputakaan, misalnya melaksanakan diskusi, untuk membahas suatu topik atau pencarian nahan pustaka. Selain itu film untuk menambah pengetahuan pembaca. Perpustakaan perlu bekerja keras mencarikan bahan pustaka yang dibutuhkan pengguna, sekalipun meminjam keperpustakaan lain. Sebagai misal, mencari buku atau jurnal ke perpustakaan lain di dalam Negeri, bahkan bila sangat perlu ke perpustakaan luar negeri.

Peneliti terdahulu yang mengkaji pelayanan publik dan kepuasan pengunjung adalah Ismerisa, (2013) dengan judul Pengaruh Pelayanan Terhadap Kepuasan Pelanggan (Survey pada Pelanggan Listrik Pintar PT. PLN (Persero) Area Yogyakarta). Hasil penelitian menunjukkan bahwa besarnya variabel pelayanan terhadap variable kepuasan konsumen dapat dilihat dari besarnya korelasi seluruh butir pernyataan variable mempunyai $r$ hitung $>r$ tabel dengan $r$ tabel; $=0,361$ dan dinyatakan reliabel jika mempunyai $r$ hitung $>r$ tabel dengan koefisien reliabilitas $r$ tabel $=0,60$ seluruh item dinyatakan valid dan reliabel.

Kualitas pelayanan unit pelayanan listrik pintar berpengaruh positif terhadap kepuasan pelanggan, artinya apabila naik atau semakin tinggi tingkat kepuasan pelanggan listrik pintar PT. PLN (persero) area Yogyakarta dan Bilgah (2018) dengan judul Pengaruh Pelayanan Publik Terhadap Kepuasan Pelanggan Pada Dinas Perhubungan Kota Depok.

Hasil penelitian menunjukkan bahwa Dalam memberikan pelayanan yang berkualitas pada masyarakat dalam hal ini pelanggan yang datang, Kantor Dinas Perhungan Kota Depok memiliki tujuan untuk menciptakan pelayanan yang optimal agar masyarakat merasa nyaman dan puas atas pelayanan yang diberikan pelaksana layanan 
selalu sigap dalam memberikan melayani kepada pelanggan berpengaruh positif terhadap kepuasan warga. Pengertian pelayanan (service) menurut American Marketting Association, seperti yang dikutip oleh Donald dalam Hardiyansyah (2018) bahwa pelayanan adalah kegiatan atau manfaat yang ditawarkan oleh suatu organisasi kepada pihak lain, yang hakekatnya tidak berwujud serta tidak menyebabkan kepemilikan sesuatu, proses produksinya mungkin juga tidak dikaitkan dengan suatu produksi fisik.

Sedangkan menurut Lovelock dalam Hardiyansyah (2018) bahwa: service adalah produk tidak berwujud, berlangsung seketika dan dirasakan atau dialami. Artinya service atau jasa merupakan produk yang tidak berwujud sehingga tidak dapat dimiliki, dan berlangsung sesaat, tidak bertahan lama, tetapi dialami dan dirasakan oleh penerima layanan. Kepuasan pengunjung, menurut Thamrin \& Francis (2012:38) merupakan kepuasan atau tingkat perasaan seseorang setelah membandingkan kinerja (hasil) yang didapatkannya dengan harapannya. Jadi tingkat kepuasan adalah fungsi atau perbedaan antara kinerja yang dirasakan (perceived performance) dengan harapan (expectations). Pelanggan bisa mengalami salah satu dari tingkat kepuasan yang umum. Jika kinerja dibawah harapan, pelanggan akan tidak puas.

Jika kinerja sesuai dengan harapan, pelanggan akan puas. Jika kinerja melampaui harapan, pelanggan akan sangat puas, senang, atau bahagia. Sedangkan kepuasan pelanggan adalah hasil yang dirasakan pembeli dari kinerja perusahaan yang memenuhi harapan mereka. Pelanggan puas apabila harapan mereka dipenuhi dan senang atau bahagia bila harapan mereka dilebihi. Pelanggan yang puas akan setia lebih lama, membeli lebih banyak, kurang sensitif pada harga, dan memberikan komentar baik tentang perusahaan. Berdasarkan Surat Keputusan Menteri Pendayagunaan Aparatur Negara Nomor (25/M.PAN/ 2004) menginstruksikan kepada seluruh instansi/lembaga penyedian layanan publik agar melakukan survei indeks kepuasan masyarakat terhadap pelayanan publik.Dengan mengacu pada prinsip-prinsip pelayanan, maka unsur-unsur 
yang harus ada dalam penilaian indeks kepuasan masyarakat harus bersifat relevan, valid dan reliable.

Kenedy dan Young dalam Supranto (2006) mengilustrasikan penggunaan kuesioner kepuasan pelanggan, kuesioner di dasarkan atas dimensi mutu pelayanan/kualitas pelayanan yang sifatnya umum. Faktor-faktor yang berpengaruh terhadap kepuasan pelanggan erat kaitannya dengan dimensi mutu pelayanan, mutu pelayanan yang baik dan adil akan menimbulkan kepuasan, sebaliknya apabila dimensi kualitas pelayanan yang buruk akan menimbulkan ketidakpuasan.

Penelitian ini bertujuan menganalisis dan menguji pengaruh tiga variabel bebas terhadap kepuasaan pelanggan. Tiga variebal bebas: sumber daya manusia, sarana dan prasarana, dan sistem informasi. Model penelitian ini digambarkan dalam Gambar 1.

\section{Gambar 1.}

\section{Model Penelitian}

Sumber Daya Manusia

$\left(X_{1}\right)$

1. Memahami bidangnya masing-masing

2. Pengetahuan

3. Kemampuan

4. Semangat kerja

5. Kemampuan pengorganisasian

(Nurianna, 2008)

Sarana dan Prasarana

$\left(X_{2}\right)$

1. Pertimbangan/perencanaan

2. Perencanaan ruang

3. Perlengkapan/perabotan

4. Unsur pendukung

5. Pesan-pesan yang disampaikan secara grafis (Jogiyanto, 2007)

Sistem Informasi

$\left(X_{3}\right)$

1. Kecepatan

2. Keandalan

3. Kelengkapan

4. Kemudahan

5. Kulewesan sistem

(Tjiptono, 2001))
Kepuasan Pengunjung

(Y)

1. Kualitas produk

2. Kualitas pelayanan

3. Emosional

4. Harga

5. Kemudahan

(Utama, 2017) 


\section{METODE PENELITIAN}

Lokasi dan Waktu Penelitian Penelitian ini berlokasi Perpustakaan dan Arsip Daerah Provinsi Papua. Peneliti menetapkan para pengunjung tersebut sebagai tempat penelitian karena ingin mengetahui seberapa jauh pengaruh kualitas pelayanan itu terhadap kepuasan pengunjung Perpustakaan Provinsi Papua Adapun waktu penelitian dilaksanakan yaitu dimulai pda bulan Januari sampai Februari 2019.

Populasi penelitian adalah pengunjung dan memiliki kartu perpustakaan pada tahun 2018, yaitu 10.122 pengunjung, berdasarkan buku pengunjung. Berdasarkan jumlah pengunjung, rata-rata pengunjung perhari 35 orang, jumlah pengunjung perminggu yaitu sebanyak 210 pengunjung. Dengan menggunakan rumus Slovin, maka sampel dalam penelitian ini adalah sebanyak 137 orang pengunjung. Metode yang digunakan dalam penarikan sampel ini adalah sampling insidental. Pengambilan sampel dalam penelitian ini menggunakan simple random sampling.

Penelitian dilakukan selama 1 minggu (6 hari) dengan kuisioner disiapkan sebanyak 210 untuk pengunjung perminggu, akan tetapi pengunjung yang mengisi dan mengembalikan kuisioner hanya sebanyak 61 orang pengunjung atau sekitar $29 \%$ ari target yang ditetapkan.

Untuk mengetahui ada atau tidaknya pengaruh antara tiga variabel bebas (X1, X2, dan $\mathrm{X} 3$ ) dengan variabel terikat $(\mathrm{Y})$ dipergunakan analisis regresi linier dengan rumus adalah sebagai berikut :

$$
Y=a+B 1 X 1+B 2 X 2+B 3 X 3+e .
$$

Keterangan :

$\mathrm{Y} \quad$ : Kepuasan pengunjung

$\mathrm{X} 1 \quad$ : Sumber Daya Manusia

X2 : Sarana dan Prasarana 
X3 : Sistem informasi

B : Koofisien Regresi

a : Konstanta

e : Error

Uji Hipotesis Uji F Analisis regresi secara multivariate dengan menggunakan metode uji f dengan taraf signifikansi $5 \%$ untuk mengetahui pengaruh seluruh variabel independen secara serentak atau simultan terhadap variabel dependen.

Uji ini dilajutkan dengan melihat nilai probabilitas, jika nilai probabilitas $>0,05$ dan nilai $f$ tabel lebih besar dari nilai $f$ hitung maka $\mathrm{H} 0$ diterima dan $\mathrm{H}$ alternatif ditolak, yang berarti tidak ada pengaruh yang signifikan secara serentak variabel independen terhadap variabel dependen. Uji t Uji t dilakukan untuk menguji secara parsial atau individu, pengaruh dari variabel bebas $(\mathrm{X})$ yang dihasilkan dari persamaan regresi secara individu berpengaruh terhadap nilai variabel terikat $(Y)$. Uji statistik $t$ dalam penelitian inidiuji dengan tingkat signifikansi (a) sebesra 0,05 atau $5 \%$.

Menurut Santoso (2002) dasar pengambilan keputusan berdasarkan perbandingan thitung dengan ttabel. Jika Fhitung > Ftabel maka Ho ditolak dan Ha diterima dan jika thitung $<$ ttabel maka Ho diterima dan Ha ditolak. Atau berdasarkan nilai probabilitas, jika probabilitas $>$ 0,05 maka Ho diterima (nonsignifikan) dan jika probabilitas $<0,05$ maka Ho ditolak (signifikan).

Defenisi Operasional

- Sumber daya manusia (SDM) merupakan petugas perpustakaan (pustakawan) yang bertugas untuk melayani pengunjung perpustakaan pada Dinas Perpustakaan dan Arsip Daerah Provinsi Papua. Adapun indikator penilaian sumber daya manusia (SDM) adalah sebagai berikut : Memahami bidang tugas, mmiliki pengetahuan, kemampuan, dan semangat kerja, serta kemampuan pengorganisasian.

- Sarana dan Prasarana adalah ketersediaan sarana dan prasarana dalam 
kegiatan perpustakaan pada Dinas Perpustakaan dan Arsip Daerah Provinsi Papua. Adapun indikator penilaian sarana dan prasarana adalah sebagai berikut : perencanaan ruang, perlengkapan dan perabotan, serta unsur pendukung, termasuk pesan-pesan yang disampaikan secara grafis

- Sistem informasi adalah ketersediaan penggunaan IT untuk menunjang kegiatan perpustakaan. Adapun indikator penilaian sistem informasi adalah sebagai berikut: kecepatan, keandalan, kelengkapan, kemudahan, keluwesan sistem Kepuasan pengunjung adalah perasaan puas atau kenyamanan yang dirasakan pengunjung terhadap pelayanan di perpustakaan.

- Adapun indikator penilaian kepuasan pengunjung adalah sebagai berikut : Kualitas produk Kualitas pelayanan Emosional Harga Kemudahan

\section{HASIL DAN PEMBAHASAN}

Dinas Perpustakaan dan Arsip Daerah Provinsi Papua dibentuk melalui Peraturan Daerah Provinsi Papua Nomor 19 Tahun 2016 tentang Pembentukan dan Susunan Perangkat daerah, perlu diatur lebih lanjut uraian tugas dan fungsi Badan Perpustakaan dan Arsip Daerah Provinsi Papua. Tugas dan Fungsi Dinas Peepustakaan dan Arsip diatur oleh Peraturan Gubernur Papua nomor 40 tahun 2015 tentang Uraian Tugas dan Fungsi Badan Perpustakaan dan Arsip Daerah Provinsi Papua.

Hasil analisis regresi diperlukan guna mengetahui koefisien-koefisien regresi serta signifikansi sehingga dapat dipergunakan untuk menjawab hipotesis. 
Tabel 1. Hasil Analisis Regresi Berganda

\section{Coefficients $^{\mathrm{a}}$}

\begin{tabular}{|c|c|c|c|c|c|c|}
\hline \multirow{2}{*}{\multicolumn{2}{|c|}{ Model }} & \multicolumn{2}{|c|}{$\begin{array}{l}\text { Unstandardized } \\
\text { Coefficients }\end{array}$} & \multirow{2}{*}{$\begin{array}{c}\text { Standardized } \\
\text { Coefficients } \\
\text { Beta }\end{array}$} & \multirow[b]{2}{*}{$l$} & \multirow[b]{2}{*}{ Sig. } \\
\hline & & $B$ & Std. Error & & & \\
\hline 1 & $\begin{array}{l}\text { (Consta } \\
\text { nt) }\end{array}$ & 502, & 2,930 & & , 171 & \\
\hline & $\mathrm{X} 1$ & ,666 & ,099 & ,619 & 6,749 &, 000 \\
\hline & $\mathrm{X} 2$ & ,233 & ,095 & ,234 & 2,467 & ,017 \\
\hline & X3 &, 106 & ,091 &, 106 & 1,167 & ,248 \\
\hline
\end{tabular}

a. Dependent Variable: $Y$

Berdasarkan tabel diatas menunjukkan persamaan regresi adalah sebagai berikut :

$$
Y=0,502+0,666 X_{1}+0,233 X_{2}+0,106 X_{3}+e
$$

Dari persamaan regresi tersebut dapat dijelaskan bahwa sumber daya manusia, sarana dan prasarana, dan sistem informasi berpengaruh positif terhadap kepuasan pengunjung pada Dinas Perpustakaan dan Arsip Daerah Provinsi Papua.

Nilai konstanta 0,502 menunjukkan bahwa apabila variabel sumber daya manusia, sarana dan prasarana, dan sitem informasi dalam kondisi tetap atau konstan, maka kepuasan pengunjung sebesar 0,502 satuan, yang berarti bahwa tanpa adanya variabel bebas yaitu sumber daya manusia, sarana dan prasarana, dan sistem informasi, maka kepuasan pengunjung akan tetap sebesar 0,502.

Nilai koefisien regresi variabel sumber daya manusia terhadap kepuasan pengunjung sebesar 0,666 dengan tanda positif artinya apabila indikator-indikator sumber daya manusia meningkat, maka akan meningkatkan kepuasan pengunjung, jika variabel lainnya dianggap konstan/tetap.

Nilai koefisien regresi variabel sarana dan prasarana terhadap kepuasan pengungjung sebesar 0,233 dengan tanda positif artinya apabila indikator-indikator sarana dan prasarana meningkat, maka akan meningkatkan kepuasan pengunjung, jika variabel lainnya dianggap konstan/tetap. 
Nilai koefisien regresi variabel sistem informasi terhadap kepuasan pengunjung sebesar 0,106 dengan tanda positif artinya apabila indikator-indikator sistem informasi meningkat, maka akan meningkatkan kepuasan pengunjung, jika variabel lainnya dianggap konstan/tetap.

\section{Uji Parsial (Uji t)}

a. Pengaruh sumber daya manusia terhadap kepuasan pengunjung. Berdasarkan hasil pengolahan data diperoleh nilai $t_{\text {hitung }}$ sebesar 6,749 $>t_{\text {tabel }}$ sebesar 1,672 dan nilai signifikansi atau probabilitas sebesar 0,000 < taraf signifikansi 5\% atau 0,05 artinya ada pengaruh positif dan signifikan sumber daya manusia terhadap kepuasan pengunjung pada Dinas Perpustakaan dan Arsip Daerah Provinsi Papua.

b. Pengaruh sarana dan prasarana terhadap kepuasan pengunjung. Berdasarkan hasil pengolahan data diperoleh nilai $t_{\text {hitung }}$ sebesar $2,467>t_{\text {tabel }}$ sebesar 1,672 dan nilai signifikansi atau probabilitas sebesar 0,017 < taraf signifikansi 5\% atau 0,05 artinya ada pengaruh positif dan signifikan sarana dan prasarana terhadap kepuasan pengunjung pada Dinas Perpustakaan dan Arsip Daerah Provinsi Papua.

c. Pengaruh Sistem Informasi terhadap kepuasan pengunjung. Berdasarkan hasil pengolahan data diperoleh nilai $t_{\text {hitung }}$ sebesar 1,167 < tabel sebesar 1,672 dan nilai signifikansi atau probabilitas sebesar 0,248 > taraf signifikansi 5\% atau 0,05 artinya tidak ada pengaruh positif dan signifikan sistem informasi terhadap kepuasan pengunjung pada Dinas Perpustakaan dan Arsip Daerah Provinsi Papua.

Berdasarkan hasil uji t diatas menunjukkan bahwa variabel yang paling dominan berpengaruh terhadap kepuasan pengunjung pada Dinas Perpustakaan dan Arsip Daerah Provinsi Papua adalah variabel sumber daya manusia $(\mathrm{SDM})\left(\mathrm{X}_{1}\right)$ karena memiliki nilai thitung yang lebih besar yaitu 6,749 dengan nilai signifikansi sebesar 0,000 dibandingkan dengan nilai thitung variabel sarana dan prasarana $(2,467)$ dan sistem informasi $(1,167)$. 


\section{Uji Simultan (Uji F)}

Adapun hasil dari uji simultan atau uji f adalah sebagai berikut :

Tabel 2. Uji Simultan (Uji F)

ANOVA $^{\mathrm{a}}$

\begin{tabular}{|ll|r|r|r|c|c|}
\hline Model & & Sum of Squares & \multicolumn{1}{c|}{ df } & Mean Square & $\mathrm{F}$ & Sig. \\
\hline 1 & Regression & 166,091 & 3 & 55,364 & 24,908 &, $000^{\mathrm{b}}$ \\
& Residual & 126,696 & 57 & 2,223 & & \\
& Total & 292,787 & 60 & & & \\
\hline
\end{tabular}

a. Dependent Variable: $Y$

b. Predictors: (Constant), X3, X1, X2

Dari tabel diatas didapatakan angka $F_{\text {hitung }}$ antara variabel sumber daya manusia, sarana dan prasarana, dan sistem informasi terhadap kepuasan pengunjung pada pada Dinas Perpustakaan dan Arsip Daerah Provinsi Papua secara simultan yaitu sebesar 24,908 lebih besar dibandingkan dengan nilai $F_{\text {tabel }}$ yaitu 2,74 dan nilai probabilitas sebesar 0,000 lebih kecil dibandingkan dengan taraf signifikan $5 \%$ atau 0,05 . Sehingga dapat disimpulkan bahwa ada pengaruh positif dan signifikan antara sumber daya manusia, sarana dan prasarana, dan sistem informasi terhadap kepuasan pengunjung pada Dinas Perpustakaan dan Arsip Daerah Provinsi Papua secara simultan atau bersama-sama.

Berdasarkan hasil uji t diatas menunjukkan bahwa variabel yang paling dominan berpengaruh terhadap kepuasan pengunjung pada Dinas Perpustakaan dan Arsip Daerah Provinsi Papua adalah variabel sumber daya manusia (SDM) (X1) karena memiliki nilai thitung yang lebih besar yaitu 6,749 dengan nilai signifikansi sebesar 0,000 dibandingkan dengan nilai thitung variabel sarana dan prasarana $(2,467)$ dan sistem informasi $(1,167)$.

Sumber daya manusia merupakan komponen penting dalam organisasi yang akan bergerak dan melakukan aktifitas untuk mencapai tujuan. Keberhasilan suatu organisasi ditentukan dari kualitas orang-orang yang berada di dalamnya. Sumber Daya Manusia akan bekerja secara optimal jika organisasi dapat mendukung kemajuan karir mereka 
dengan melihat apa sebenarnya kompetensi mereka.

Berdasarkan hasil penelitian dan pengolahan data yang dilakukan menunjukkan bahwa nilai rata-rata jawaban responden tentang pernyataan yang berhubungan dengan sumber daya manusia yaitu sebesar 4,51. Hal ini berarti penempatan sumber daya manusia pada Dinas Perpustakaan dan Arsip Daerah Provinsi Papua sudash sesuai dengan keahlianny masing-masing, sumber daya manusia mempunyai pengetahuan yang luas tentang yang berhubungan dengan buku-buku yang ada perpustakaan, sumber daya manusia mampu dalam memenuhi permintaan pengunjung, Sumber daya manusia mempunyai semangat kerja yang besar dalam melayani pengunjung, dan sumber daya manusia pada Dinas Perpustakaan dan Arsip Daerah Provinsi Papua selalu mampu memberikan pelayanan terbaik dimanapun dia ditempatkan.

Hasil pengolahan data juga menunjukkan bahwa ada pengaruh positif dan signifikan sumber daya manusia terhadap kepuasan pengunjung pada Dinas Perpustakaan dan Arsip Daerah Provinsi Papua. Sejalan dengan penelitian terdahulu yang dilakukan oleh Andi Pandita (2017) dengan hasil penelitian menunjukkan bahwa kualitas pelayanan dalam hal ini adalah Sumber Daya Manusia mempunyai pengaruh positif dan signifikan terhadap kepuasan pemustaka.

Pengaruh sarana dan prasarana terhadap kepuasan pengunjung. Penyediaan sarana dan prasarana di perpustakaan merupakan hal yang penting karena dapat menunjang kelancaran kegiatan perpustakaan secara optimal sehingga tugas dan fungsi perpustakaan perguruan tinggi dapat terlaksana. Sarana dan prasarana dapat dibedakan menjadi dua yaitu sarana dan prasarana fisik dan sarana dan prasarana non fisik. Berdasarkan hasil penelitian menunjukkan bahwa rata-rata nilai jawaban responden tentang pernyataan yang berhubungan dengan sarana dan prasarana yaitu sebesar 4,55. Hal ini berarti bahwa bahwa gedung dan fasilitas yang ada di perpustakaan sudah lengkap, desain perpustakaan sudah baik, ruangan pada perpustakaan sudah bersih, 
koleksi buku yang ada di perpustakaan selalu up to date (terbaru), dan koleksi yang ada tersedia di perpustakaan sudah sesuai dengan kebutuhan para pengunjung.

Hasil pengolahan data yang dilakukan menunjukkan bahwa ada pengaruh positif dan signifikan sarana dan prasarana terhadap kepuasan pengunjung. Hal ini menunjukkan bahwa indikator variabel sarana dan prasarana sudah berjalan dengan baik. Sejalan dengan penelitian terdahulu yang dilakukan oleh Ismerisa (2013) dengan hasil penelitian menunjukkan bahwa kualitas pelayanan (sarana dan prasarana) mempunyai pengaruh yang positif dan signifikan terhadap kepuasan pelanggan.

Pada Dinas Perpustakaan dan Arsip Daerah Provinsi Papua masih terdapat beberapa kekurangan dalam hal sarana dan prasasarana. Hal ini dapat dilihat dari masih perlu di tambahkan ruang untuk para pembaca, perlengkapan komputer yang masih perlu ditambahkan, dan juga juga koleksi buku yang masih perlu ditambahkan karena masih terdapat beberapa buku yang belum ada pada perpustakaan. Beberapa hal tersebut merupakan bagian dari sarana dan prasarana yang dapat menunjang peningkatan jumah dan kepuasan pengunjung perpustakaan pada Dinas Perpustakaan dan Arsip daerah Provinsi Papua. Pengaruh sistem informasi terhadap kepuasan pengunjung pada Dinas Perpustakaan dan Arsip Daerah Provinsi Papua. Sistem informasi adalah suatu sistem didalam suatu organisasi yang mempertemukan kebutuhan pengolahan transaksi harian yang mendukung fungsi operasi organisasi yang bersifat manajerial dengan kegiatan strategi dari suatu organisasi untuk dapat menyediakan kepada pihak luar tertentu dengan laporan laporan yang diperlukan.

Berdasarkan hasil penelitian yang dilakukan menunjukkan bahwa rata-rata skor jawaban responden tentang pernyataan yang berhubungan dengan sistem informasi yaitu sebesar 4,56. Hal menunjukkan bahwa sistem layanan terbuka (open access) memudahkan pengunjung dalam mencari dan memilih koleksi yang dibutuhkan, prosedur peminjaman koleksi pada perpustakaan sudah berjalan dengan baik, prosedur 
pengembalian koleksi perpustakaan sudah dianggap baik oleh pengunjung, petugas layanan sirkulasi komunikatif sudah baik dalam memberikan pelayanan kepada pengunjung, pengunjung merasa perlu adanya petunjuk atau rambu-rambu diperpustakaan.

Berdasarkan hasil pengolahan data yang dilakukan menunjukkan bahwa ada pengaruh positif tetapi tidak signifikan sistem informasi terhadap kepuasan pengunjung Dinas Perpustakaan dan Arsip Daerah Provinsi Papua. Hal ini dapat dilihat dari nilai thitung sebesar $1,167<$ ttabel sebesar 1,672 dan nilai signifikansi atau probabilitas sebesar 0,248 > taraf signifikansi $5 \%$ atau 0,05.

Berbanding terbalik dengan penelitian terdahulu yang dilakukan oleh Bilgah (2018) dengan hasil penelitian menunjukkan bahwa pelayanan publik (sistem informasi) mempunyai pengaruh positif dan signifikan terhadap kepuasan pelanggan. Pada Dinas Perpustakaan dan Arsip Daerah Provinsi masih terdapat beberapa hal yang menyembabkan kurangnya sistem informasi pada perpustakaan.

Hal ini dapat dilihat dari masih terdapat beberapa petugas perpustakaan kurang cepat dalam menanggapi permintaan dari pengunjung, dan kelengkapan sarana dan prasarana yang masih kurang sehingga berdampak lambatnya sistem informasi pada perpustakaan. Beberapa hal tersebut yang menyebabkan sistem informasi masih kurang pada perpustakaan sehingga berdampak kepada berkurangnya juga kepuasan para pengunjung perpustakaan.

Pengaruh Sumber Daya Manusia (SDM), sarana dan prasarana, dan sistem informasi secara simultan terhadap kepuasan pengunjung pada Dinas Perpustakaan dan Arsip Daerah Provinsi Papua. Kepuasan adalah suatu sikap yang diputuskan berdasarkan pengalaman yang didapatkan. Kepuasan merupakan penilaian mengenai ciri atau keistimewaan produk atau jasa, atau produk itu sendiri, yang menyediakan tingkat kesenangan konsumen berkaitan dengan pemenuhan kebutuhan konsumsi konsumen. 
Kepuasan konsumen dapat diciptakan melalui kualitas, pelayanan dan nilai.

Kunci untuk menghasikan kesetian pelanggan adalah memberikan nilai pelanggan yang tinggi. Berdasarkan hasil penelitian menunjukkan bahwa rata-rata nilai jawaban responden tentang pernyataan yang berhubungan dengan kepuasan pengunjung yaitu sebesar 4,65. Hal ini berarti petugas perpustakaan selalu membantu pengunjung yang mengalami kesulitan, pengunjung sudah puas dengan semua prosedur yang berlaku di perpustakaan, pengunjung meras puas dengan pelayanan pustakawan yang bertugas, petugas pada perpustakaan mempunyai pengetahuan yang luas dan baik, dan juga pengunjung sudah nyaman dengan kondisi perpustakaan.

Berdasarkan hasil pengolahan data menunjukkan bahwa ada pengaruh positif dan signifikan antara sumber daya manusia, sarana dan prasarana, dan sistem informasi terhadap kepuasan pengunjung Dinas Perpustakaan dan Arsip Daerah Provinsi Papua secara simultan atau bersama-sama. Hal ini dapat dilihat dari angka Fhitung antara variabel sumber daya manusia, sarana dan prasarana, dan sistem informasi terhadap kepuasan pengunjung Dinas Perpustakaan dan Arsip Daerah Provinsi Papua secara simultan yaitu sebesar 24,908 lebih besar dibandingkan dengan nilai Ftabel yaitu 2,74 dan nilai probabilitas sebesar 0,000 lebih kecil dibandingkan dengan taraf signifikan $5 \%$ atau 0,05 .

Dalam upaya meningkatkan kepuasan pengunjung Dinas Perpustakaan dan Arsip Perpustakaan Daerah Provinsi Papua selalu melakukan upaya-upaya dalam mengembangkan perpustakaan. Faktor diantara Sumber Daya Manusia (SDM, sarana dan prasarana, dan sistem informasi yang lebih berpengaruh dominan terhadap kepuasan pengunjung pada Dinas Perpustakaan dan Arsip Daerah Provinsi Papua. Urusan Wajib Non Pelayanan Dasar perpustakaan dan kearsipan merupakan urusan pemerintahan wajib yang tidak berkaitan pelayanan dasar.

Dalam kerangka urusan ini Dinas Perpustakaan dan Arsip daerah Provinsi Papua 
memiliki tugas dan tanggungjawab yang setara dengan perangkat daerah yang masingmasing memiliki tugas dan tanggungjawab dalam penyelenggaraan pemerintahan daerah. Berdasarkan hasil penelitian dan pengolahan data yang dilakukan menunjukkan bahwa variabel yang paling dominan berpengaruh terhadap kepuasan pengunjung pada Dinas Perpustakaan dan Arsip Daerah Provinsi Papua adalah variabel sumber daya manusia (SDM) (X1) karena memiliki nilai thitung yang lebih besar yaitu 6,749 dengan nilai signifikansi sebesar 0,000 dibandingkan dengan nilai thitung variabel sarana dan prasarana $(2,467)$ dan sistem informasi $(1,167)$.

Dinas Peprustakaan dan Arsip daerah Provinsi Papua sesuai dengan tugas dan tanggungjawabnya terus berupaya untuk memberikan kinerja pelayanan kepada masyarakat, aparatur, pihak-pihak lainnya yang memerlukan pelayanan perpustakaan maupun pelayanan kearsipan. PENUTUP Kesimpulan Sumber daya manusia mempunyai pengaruh yang signifikan terhadap kepuasan pengunjung Dinas Perpustakaan dan Arsip Daerah Provinsi Papua.

Sarana dan prasarana mempunyai pengaruh yang signifikan terhadap kepuasan pengunjung Dinas Perpustakaan dan Arsip Daerah Provinsi Papua. Sistem informasi tidak mempunyai pengaruh yang signifikan terhadap kepuasan pengunjung Dinas Perpustakaan dan Arsip Daerah Provinsi Papua Sumber daya manusia, sarana dan prasarana, dan sistem informasi secara bersama-sama mempunyai pengaruh yang signifikan terhadap kepuasan pengunjung Dinas Perpustakaan dan Arsip Daerah Provinsi Papua.

Faktor yang paling dominan berpengaruh terhadap kepuasan pengunjung pada Dinas Perpustakaan dan Arsip Daerah Provinsi Papua adalah Faktor sumber daya manusia (SDM). 


\section{KESIMPULAN}

Studi ini menemukan faktor sumber daya manusia, sarana dan prasarana, dan sistem informasi mempunyai pengaruh terhadap kepuasan pengunjung. Pengaruh sumber daya manusia dan sarana/prasarana secara statistik signifikan, namun pengaruh sistem informasi tidak signifikan. Secara bersama ketiga variabel bebas ini mempunyai pengaruh yang signifikan. Faktor yang paling dominan adalah sumber daya manusia.

\section{KETERBATASAN PENELITIAN}

Faktor-faktor yang mempengaruhi kepuasan pengunjung dalam penelitian ini hanya terdiri dari tiga variabel, yaitu sumber daya manusia (SDM), sarana dan prasarana, dan sistem informasi, sedangkan masih banyak faktor lain yang mempengaruhi kepuasan pengunjung. Adanya keterbatasan penelitian dengan menggunakan kuisioner yaitu terkadang jawabn yang diberikan oleh sampel atau responden tidak menunjukkan keadaan sesuangguhnya.

\section{DAFTAR PUSTAKA}

Bilgah. (2018). PENGARUH PELAYANAN PUBLIK TERHADAP KEPUASAN PELANGGAN PADA DINAS PERHUBUNGAN KOTA DEPOK. Retrieved from https://ejournal.bsi.ac.id/ejurnal/index.php/cakrawala/article/download/3408/2349

Hardiyansyah, H. (2018). Kualitas Pelayanan Publik: Konsep, Dimensi, Indikator dan Implementasinya. Gava Media.

Ismerisa. (2013). PENGARUH PELAYANAN TERHADAP KEPUASAN PELANGGAN. Negara, M. P. A. (2004). Perubahan Peraturan Kementrian Pendayagunaan Aparatur Negara No. 09/KEPM. PAN. 2002.

PANDITA, A. (n.d.). PENGARUH KUALITAS PELAYANAN TERHADAP KEPUASAN PEMUSTAKA DI UPT PERPUSTAKAAN UNIVERSITAS NEGERI MAKASSAR.

Supranto, J. (2006). Pengukuran tingkat kepuasan pelanggan untuk menaikkan pangsa pasar. Jakarta: Rineka Cipta.

Thamrin, A., \& Francis, T. (2012). Manajemen pemasaran. Jakarta: PT RajaGrafindo Persada.

Vauthey, S., Santoso, S., Gong, H., Watson, N., \& Zhang, S. (2002). Molecular selfassembly of surfactant-like peptides to form nanotubes and nanovesicles. Proceedings of the National Academy of Sciences, 99(8), 5355-5360. 